\title{
Comparison of treatments to inactivate viral hemorrhagic septicemia virus (VHSV-IVb) in frozen baitfish
}

\author{
Nicholas B. D. Phelps ${ }^{1, *}$, Andrew E. Goodwin ${ }^{2}$, Emily Marecaux ${ }^{2}$, Sagar M. Goyal ${ }^{1}$ \\ ${ }^{1}$ Veterinary Population Medicine, College of Veterinary Medicine, University of Minnesota, 1333 Gortner Avenue, \\ Saint Paul, Minnesota 55108, USA \\ ${ }^{2}$ Aquaculture/Fisheries Center, University of Arkansas at Pine Bluff, 1200 North University Drive, \\ Pine Bluff, Arkansas 71601, USA
}

\begin{abstract}
Current US state and federal fish health regulations target the spread of viral hemorrhagic septicemia virus-IVb (VHSV-IVb) through movement restrictions of live fish; however, they largely ignore the potential for the virus to be spread through commercial distribution and use of frozen baitfish from VHSV-IVb-positive regions. Some state laws do require treatment of frozen baitfish to inactivate VHSV, and additional methods have been proposed, but few scientific studies have examined the efficacy of these treatments. In this study, bluegills Lepomis macrochirus were challenged with VHSV-IVb and frozen to represent standard industry methods, disinfected by various treatments, and tested for infectious VHSV-IVb using virus isolation. The virus was isolated from $70 \%$ of fish subjected to 3 freeze/thaw cycles. All other treatment methods were effective in inactivating the virus, including treatment with isopropyl alcohol, mineral oil, salt and borax, and dehydration. Dehydration followed by rehydration is rapid and effective, and therefore, seems to be the best option for inactivating VHSV-IVb present in frozen baitfish while maintaining their usefulness as bait.
\end{abstract}

KEY WORDS: VHS · Inactivation $\cdot$ Dehydration $\cdot$ Bluegill

\section{INTRODUCTION}

Viral hemorrhagic septicemia virus (VHSV) strain $\mathrm{IVb}$ was first isolated from the North American Great Lakes in 2003 (Elsayed et al. 2006, Lumsden et al. 2007). Since then, the virus has spread throughout the Great Lakes basin, causing large mortality events in a wide variety of species. The route by which VSHV entered the Great Lakes is unknown; however, water connectivity and natural fish movement continue to distribute the virus (Thompson et al. 2011). Of particular concern has been the spread of VHSV-IVb to inland lakes, including lakes outside the watershed. In these cases, likely transmission routes include water, fomites, and movements of fish for stock enhancement and bait (Bain et al. 2010, VHSV Expert Panel \& Working Group 2010).

The potential to inadvertently move aquatic animal pathogens to new regions through shipments of baitfish is a concern for fish health managers (Hedrick 1996, Harvell et al. 1999, Gaughan 2001, Goodwin et al. 2004). Baitfish are often used in close proximity to their source; however, larger numbers of live and frozen baitfish captured from the wild are moved and released into new regions far from their origins (Goodwin et al. 2004). Frozen baitfish are particularly concerning, given the large harvest volume, wide geographic distribution, and evidence that freezing is not sufficient to inactivate all viruses present in 
infected fish (Meyers et al. 1999, Gaughan 2001, Arkush et al. 2006, Hervé-Claude et al. 2008). In fact, freezing $\left(-20\right.$ to $\left.-10^{\circ} \mathrm{C}\right)$ has been shown to be suitable for preservation of a variety of viruses in fish tissue (Plumb et al. 1973, Burke \& Mulcahy 1983, Plumb \& Zilberg 1999).

Several well-documented examples of fish disease introductions appear to have been caused by movements of frozen baitfish. In 1995 and 1998, outbreaks of the pilchard herpes virus (PHV) in Australia resulted in fish kills and a 70\% decline of the spawning biomass of sardines Sardinops sagax (also known as pilchards; Gaughan 2001). The PHV is believed to have been exported to Australia in frozen and unprocessed sardines that were fed to tuna raised in sea pens (Hyatt et al. 1997, Gaughan 2001). In 2004, more than 2500 sea bass Dicentrarchus labrax died on a farm in the Mediterranean Sea. The kill was attributed to VHSV (www.cefas.defra.gov.uk/idaad/ abstract.aspx? $t=d o \& i d=)$ and speculated to have been introduced with frozen baitfish used in a nearby tuna farm (WWF 2005).

In the US, large-volume frozen baitfish shipments originate from regions known to be VHSV positive. These involve VHS-susceptible species (OIE 2009), including sardines Sardina pilchardus from the North Atlantic and Mediterranean Sea, Pacific herring Clupea pallasi from the Pacific Northwest, and both rainbow smelt Osmerus mordax and lake herring Coregonus artedi from the Great Lakes (Arkush et al. 2006, Hervé-Claude et al. 2008).

Despite the risks of virus introduction, frozen baitfish are not regulated as stringently as their live counterparts in the US. For example, the USDAAPHIS (2008) Federal Order was established to prevent the further distribution of VHSV-IVb; however, these regulations do not pertain to frozen baitfish. In response to these threats, Minnesota and Wisconsin have recently established new regulations specifically for the use of frozen baitfish in state waters (Minnesota Rules: Part 6262.0577, subpart 2; Wisconsin Statutes: Section 10, NR 20.08), herein referred to as the current regulatory options. All frozen baitfish originating from VHSV-positive waters or those with an unknown health history must be processed to inactivate infectious virus prior to use. The approved treatment methods include submersion in either isopropyl alcohol or mineral oil for $14 \mathrm{~d}$, being covered in a salt and borax mixture for $14 \mathrm{~d}$, or dehydration followed by heating to $60^{\circ} \mathrm{C}$. Isopropyl alcohol is a well known broad-spectrum antimicrobial, effective against enveloped viruses like VHSV (Danner \& Merrill 2006, Perry \& Caveney 2012); however, it is primarily used as a surface disinfectant. The ability of isopropyl alcohol to sufficiently saturate the whole fish is unknown. Mineral oil is used to interfere with the transmission and retention of plant viruses (Wang \& Pirone 1996), but its effectiveness in animals or against VHSV is unknown. Furthermore, it seems unlikely that the highly hydrophobic mineral oil would penetrate the fish. The salt and borax treatment preserves the fish by drawing the water from the tissue, consequently dehydrating and inactivating the virus. The treated fish can then be rehydrated to regain their size (Thorarinsdottir et al. 2011). Similarly, dehydrating the whole fish removes the water, with any remaining infectious virus inactivated by heating to $60^{\circ} \mathrm{C}$.

In this study, we evaluated treatment techniques designed to inactivate VHSV in previously frozen baitfish. Our study includes both novel and standard industry methods.

\section{MATERIALS AND METHODS}

\section{Experimental infection}

Bluegills Lepomis macrochirus were obtained from a commercial fish farm with a negative history of VHSV by annual farm-level inspection (USFWS \& AFS-FHS 2010). The mean \pm SD length and weight were $11.96 \pm 0.80 \mathrm{~cm}$ and $27.10 \pm 1.12 \mathrm{~g}$. The fish $(\mathrm{n}=$ 280) were transported live to the Fish Disease Research Laboratory at the University of Arkansas at Pine Bluff, and held in a biosecure facility. The fish were divided into two 3001 recirculating systems and acclimated for $5 \mathrm{~d}$ at approximately $10^{\circ} \mathrm{C}$.

The virus used in the experimental exposure was VHSV-IVb (Lumsden et al. 2007) propagated in fathead minnow cells. Prior to challenge, all fish were anesthetized with tricaine methanesulfonate (MS222; Western Chemical). Each fish then received an intraperitoneal (IP) injection of $100 \mu \mathrm{l}$ of VHSV-IVb stock diluted 1:10 in Hank's Balanced Salt Solution (HBSS; Sigma) producing a final median tissue culture infective dose $\left(\mathrm{TCID}_{50}\right)$ of approximately $1 \times 10^{4}$ TCID $_{50}$ fish $^{-1}$. The fish were monitored daily for $7 \mathrm{~d}$ for clinical signs of VHS. This time period was selected based on data from similar challenge experiments (Goodwin \& Merry 2011). Moribund or dead fish were removed from the aquaria daily and frozen at $-80^{\circ} \mathrm{C}$. Seven days post injection, surviving fish were euthanized with an overdose of MS-222 and then frozen at $-80^{\circ} \mathrm{C}$. All fish were sent overnight on dry ice to the Minnesota Veterinary Diagnostic Labo- 
ratory (MVDL) to be treated and subsequently tested for the presence of infectious VHSV by virus isolation. Another 40 fish that were not challenged with VHSV-IVb from a known VHSV-negative waterbody in Minnesota were shipped to the MVDL on frozen ice packs and then frozen at $-80^{\circ} \mathrm{C}$. The latter served as negative control fish.

\section{VHSV disinfection treatments}

Upon receipt at the MVDL, all infected bluegills were thawed to room temperature $\left(22^{\circ} \mathrm{C}\right)$, mixed on a lab bench, and randomly allocated to 7 groups of 40 fish each. The fish underwent 6 different treatment regimens, based on current regulatory requirements for the treatment of frozen baitfish and standard industry practices. One group of challenged fish served as the positive control and was left untreated. The additional group of bluegills not exposed to VHSV-IVb served as the negative control. Unless otherwise stated, all treatment groups were held at $22^{\circ} \mathrm{C}$ in a ventilated hood for the duration of the treatment. Treatment groups were as follows:

(1) Positive control: 40 bluegills challenged with VHSV-IVb underwent no additional treatment and were immediately tested.

(2) Negative control: 40 bluegills not challenged with VHSV-IVb underwent no treatment and were immediately tested.

(3) Freeze/thaw: 40 bluegills underwent 3 cycles of freezing and thawing. These cycles were completed in a standard freezer at $-20^{\circ} \mathrm{C}$ for $16 \mathrm{~h}$ and slow thawed at $22^{\circ} \mathrm{C}$ for $8 \mathrm{~h}$, over a span of $3 \mathrm{~d}$. Fish were pooled in one freezer bag during treatment. The duration and temperature of the treatments were sufficient to thoroughly freeze and thaw all fish. These are the standard industry methods to which frozen baitfish would be subjected prior to use by the consumer in Minnesota and Wisconsin (Minnesota Department of Natural Resources, MNDNR, pers. comm.).

(4) Isopropyl alcohol: 40 bluegills were submerged in $70 \%$ isopropyl alcohol for $14 \mathrm{~d}$ in a sealable container. The ratio was approximately $542 \mathrm{~g}$ of fish to 1.51 of isopropyl alcohol (current regulatory option).

(5) Mineral oil: 40 bluegills were submerged in mineral oil (Vi-Jon) for $14 \mathrm{~d}$ in a sealable container. The ratio was approximately $542 \mathrm{~g}$ of fish to $1.5 \mathrm{l}$ of mineral oil (current regulatory option).

(6) Salt and borax: 40 bluegills were thoroughly coated in a salt and borax mixture and let stand for $14 \mathrm{~d}$. The mixture consisted of $900 \mathrm{~g}$ of non-iodized salt and $100 \mathrm{~g}$ of borax (current regulatory option).
(7) Dehydration: 40 bluegills were dehydrated in a dehydrator (Oster, Model FPSTDH0101, Sunbeam Products) at $50^{\circ} \mathrm{C}$ for $8 \mathrm{~h}$. This amount of time was shown to be sufficient to completely dry the bluegill when visually examined during necropsy (novel method).

(8) Dehydration and heat: 40 bluegills were dehydrated at $50^{\circ} \mathrm{C}$ for $8 \mathrm{~h}$. Following dehydration, the fish were placed in a laboratory oven at $60^{\circ} \mathrm{C}$ for 15 min (current regulatory option).

\section{Virus isolation}

Upon completion of each treatment, the fish were rinsed with tap water to remove treatment residue. Some fish treated in mineral oil could not be rinsed because an advanced state of decomposition rendered them too fragile. Kidney and spleen tissue was removed from groups of 2 fish each and pooled for a total of 20 pools per treatment group. Given the small size of each fish, pooling was necessary to acquire sufficient sample sizes for virus isolation. Necropsy tools were disinfected for $2 \mathrm{~min}$ in a 1:256 dilution of broad-spectrum antimicrobial (Synergize, Preserve International), then rinsed with tap water and dried between each pool to prevent contamination.

Sample preparation and virus isolation protocols followed the methods described by USFWS \& AFSFHS (2010). Briefly, a $10 \%$ suspension of the tissue pool was prepared in $2 \mathrm{ml}$ of HBSS (Sigma). The suspension was homogenized in a stomacher for $30 \mathrm{~s}$, then centrifuged at $2900 \times g\left(4^{\circ} \mathrm{C}\right.$ for $\left.15 \mathrm{~min}\right)$. An equal amount of antibiotic medium was added to the supernatant and thoroughly mixed. The suspension was incubated for $2 \mathrm{~h}$ at $15^{\circ} \mathrm{C}$ and re-centrifuged at $2900 \times g(15 \mathrm{~min})$. The resulting supernatant was used for virus isolation.

Monolayers of epithelioma papulosum cyprini (EPC) cells (Fijan et al. 1983, Winton et al. 2010) were prepared in 24 -well microtiter plates. When monolayers were $80 \%$ confluent, the cell culture medium was replaced with $100 \mu \mathrm{l}$ well $^{-1}$ of the sample suspension. The cultures were then incubated at $15^{\circ} \mathrm{C}$ for $60 \mathrm{~min}$ to allow for viral adsorption. Maintenance medium was added, and the plates were incubated at $15^{\circ} \mathrm{C}$ for $14 \mathrm{~d}$ and monitored 3 times per week for the appearance of cytopathic effect (CPE). Unless CPE was observed, all samples were blind passaged on Day 14. If no CPE appeared after an additional $14 \mathrm{~d}$ second passage, the sample was determined to be negative and no additional testing was performed. If CPE was observed, the original material was tested 
by real-time reverse transcriptase PCR (rRT-PCR) for confirmation (Phelps et al. 2012). A VHSV-IVb isolate (Great Lakes reference strain: MI03) was used as a positive control to monitor the sensitivity of the cell line to the virus.

\section{RESULTS}

\section{Experimental infection}

During the $7 \mathrm{~d}$ VHSV-IVb challenge at $10^{\circ} \mathrm{C}, 150$ bluegills were removed due to mortality or morbidity. The surviving 130 bluegills were euthanized on Day 7. Although slightly more apparent in moribund and dead fish, clinical signs of VHS (petechial and ecchymotic hemorrhage of the skin, vent, base of fins, and eye) were observed in most of the challenged fish (Fig. 1).

\section{VHSV disinfection treatments}

The overall condition of the fish post treatment varied between groups based on gross examination (Fig. 1). The isopropyl alcohol treatment preserved the fish well and appeared to penetrate the whole fish. The mineral oil treatment was not effective in preserving the fish and resulted in severe decomposition and odor. The salt and borax and the dehydration treatments effectively preserved the fish by removing water from the tissue. The freeze/thaw treatment produced the most natural product.

\section{Virus isolation}

VHSV-IVb was isolated from all positive control fish on the first cell culture passage. No virus was isolated from the negative control fish. Infectious VHSV-IVb virus was isolated from 14 of $20(70 \%)$ samples from the freeze/thaw treatment. Of the remaining treatment groups, all disinfection methods were successful in inactivating VHSV-IVb from frozen bluegills (Table 1). We observed no cytotoxic impact on virus isolation (premature cell death or ambiguous $\mathrm{CPE}$ ) as a result of any treatment residue. All tissue samples that produced CPE in culture were also positive by rRT-PCR. The mean $\pm \mathrm{SD}$ rRT-PCR threshold cycle $(\mathrm{Ct})$ for the positive control group was $22.54 \pm 2.63$ and the freeze/thaw treatment was $27.14 \pm 2.45$.

\section{DISCUSSION}

The current industry standard of freezing baitfish is not sufficient to inactivate infectious VHS-IVb, although these methods did reduce the positive samples by $30 \%$. While the purpose of freezing the baitfish is not necessarily to inactivate pathogens, it has been suggested that it may be sufficient for baitfish populations with low viral loads or effective in appropriate environmental conditions (Arkush et al. 2006). For high-risk pathogens, like VHSV-IVb, additional precautions are warranted in areas where transmission is likely. This is particularly important given that
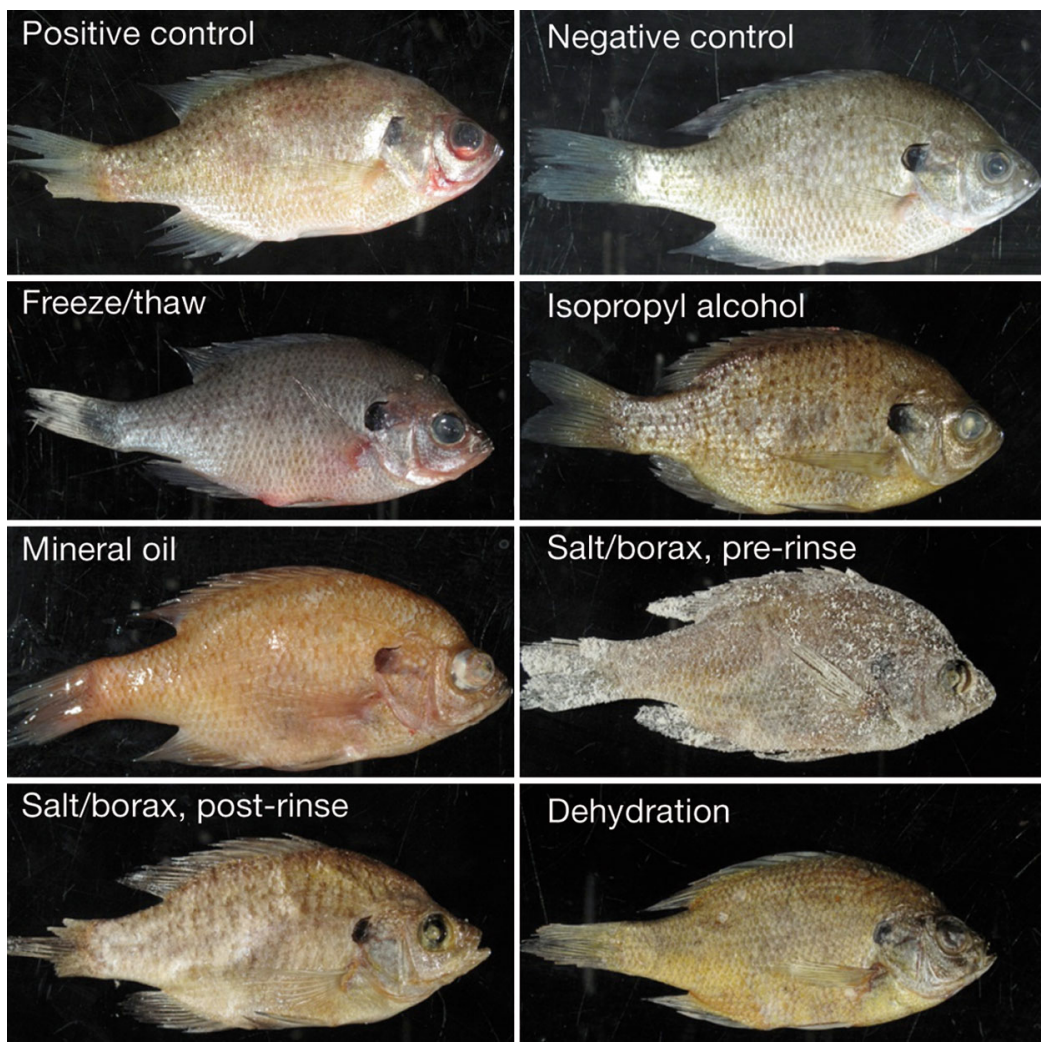

Fig. 1. Lepomis macrochirus. External condition of various viral hemorrhagic septicemia virus (VHSV) disinfection treatments on previously frozen VHSVIVb-positive bluegills. Each image is a representative fish from the various treatment groups. Treatments included positive control, negative control, freeze/thaw, isopropyl alcohol, mineral oil, salt plus borax (specimens pre and post rinse are shown), and dehydration with and without subsequent heat 
Table 1. Lepomis macrochirus. Virus isolation and rRT-PCR results of various viral hemorrhagic septicemia virus (VHSV) disinfection treatments on previously frozen VHSV-IVb-positive bluegills. Each sample (1-20) contains a pool of 2 bluegills $(\mathrm{n}=$ 40) for each treatment. Numeric values indicate the rRT-PCR threshold cycle (Ct) of cell-culture-positive samples. Minus signs show samples that were negative by cell culture (these were not tested by rRT-PCR)

\begin{tabular}{|c|c|c|c|c|c|c|c|c|}
\hline Sample & $\begin{array}{c}\text { Positive } \\
\text { control }\end{array}$ & $\begin{array}{c}\text { Negative } \\
\text { control }\end{array}$ & $\begin{array}{c}\text { Freeze/ } \\
\text { thaw }\end{array}$ & $\begin{array}{l}\text { Isopropyl } \\
\text { alcohol }\end{array}$ & $\begin{array}{l}\text { Mineral } \\
\text { oil }\end{array}$ & $\begin{array}{l}\text { Salt }+ \\
\text { borax }\end{array}$ & Dehydration & $\begin{array}{c}\text { Dehydration } \\
\text { + heat }\end{array}$ \\
\hline 1 & 21.30 & - & - & - & - & - & - & - \\
\hline 2 & 21.20 & - & - & - & - & - & - & - \\
\hline 3 & 20.71 & - & - & - & - & - & - & - \\
\hline 4 & 21.56 & - & 25.23 & - & - & - & - & - \\
\hline 5 & 21.82 & - & - & - & - & - & - & - \\
\hline 6 & 20.83 & - & 28.98 & - & - & - & - & - \\
\hline 7 & 22.80 & - & 25.50 & - & - & - & - & - \\
\hline 8 & 22.16 & - & 24.75 & - & - & - & - & - \\
\hline 9 & 20.77 & - & 25.10 & - & - & - & - & - \\
\hline 10 & 28.08 & - & 27.40 & - & - & - & - & - \\
\hline 11 & 20.35 & - & 24.65 & - & - & - & - & - \\
\hline 12 & 20.68 & - & 31.08 & - & - & - & - & - \\
\hline 13 & 28.51 & - & 24.69 & - & - & - & - & - \\
\hline 14 & 21.39 & - & 28.79 & - & - & - & - & - \\
\hline 15 & 22.34 & - & 26.80 & - & - & - & - & - \\
\hline 16 & 21.23 & - & - & - & - & - & - & - \\
\hline 17 & 26.17 & - & 30.34 & - & - & - & - & - \\
\hline 18 & 22.16 & - & 25.60 & - & - & - & - & - \\
\hline 19 & 27.12 & - & 31.06 & - & - & - & - & - \\
\hline 20 & 20.33 & - & - & - & - & - & - & - \\
\hline Mean $\pm \mathrm{SD} \mathrm{Ct}$ & $22.54 \pm 2.63$ & & $27.14 \pm 2.45$ & & & & & \\
\hline
\end{tabular}

frozen baitfish are often harvested from waters of unknown disease history, or in some cases from known VHSV-positive waters, and fed to naïve populations. However, given the diversity of baitfish and their use, a thorough risk assessment should be performed for each scenario to justify additional processing requirements.

The 4 methods (isopropyl alcohol, mineral oil, salt and borax, and dehydration and heat) currently approved by the Minnesota and Wisconsin Departments of Natural Resources were shown to be effective in reducing infectious VHSV-IVb beyond the limit of detection by virus isolation. Confidence in these methods is further increased due to the high viral loads of the challenged fish. Presumably, frozen baitfish harvested from the wild would carry considerably less virus under normal conditions. It is also important to note that the dehydration treatment without subsequent heating at $60^{\circ} \mathrm{C}$ was also shown to be effective.

In locations where these treatments are currently required, there has been some resistance from the frozen bait industry and anglers (MNDNR pers. comm.). They understand the importance of these regulations and the risk VHSV-IVb poses to wild and farmed fish populations, but adapting to new rules is challenging. In addition to increased processing costs, these treatments are time consuming and require additional handling. This burden would increase with the salt and borax or dehydration treatments because fish would need to be rehydrated to eliminate buoyancy issues. In addition, the effect of the treatment on the quality and palatability of the bait is potentially problematic, and further evaluation is needed. For example, the mineral oil treatment led to severe decomposition of tissue and an extreme odor, resulting in a product likely not suitable for use as bait. We also have concerns about the potential for clostridial growth and botulism toxin production in these fish decomposing under anaerobic conditions.

Dehydration followed by rehydration is rapid and effective, and therefore seems to be the best option for inactivating VHSV-IVb from frozen baitfish while maintaining their usefulness as bait. However, this method does pose a risk if the fish is not sufficiently dehydrated. Further species-specific investigation is needed to identify appropriate dehydration times and necessary temperatures for traditional frozen baitfish, such as Pacific herring and sardines. In addition, technological advancements or anti-viral products that do not affect baitfish taste or body condition should be considered for development. 
Acknowledgements. We thank W. Wiese and M. Schwabenlander for technical assistance on this project and the Minnesota Department of Natural Resources for providing some of the disinfectants.

\section{LITERATURE CITED}

Arkush KD, Mendonca HL, McBride AM, Yun S, McDowell TS, Hedrick RP (2006) Effects of temperature on infectivity and commercial freezing on survival of the North American strain of viral hemorrhagic septicemia virus (VHSV). Dis Aquat Org 69:145-151

Bain MB, Cornwell ER, Hope EM, Eckerlin GE and others (2010) Distribution of an invasive aquatic pathogen (viral hemorrhagic septicemia virus) in the Great Lakes and its relationship to shipping. PLoS ONE 5:e10156

$>$ Burke J, Mulcahy D (1983) Retention of infectious haematopoietic necrosis virus infectivity in fish tissue homogenates and fluids stored at three temperatures. J Fish Dis 6:543-547

Danner GR, Merrill P (2006) Disinfectants, disinfection, and biosecurity in aquaculture. In: Scarfe AD, Lee C, O'Bryen PJ (eds) Aquaculture biosecurity: prevention, control, and eradication of aquatic animal diseases. Blackwell Publishing, Oxford, p 91-128

> Elsayed E, Faisal M, Thomas M, Whelan G, Batts W, Winton $\mathrm{J}$ (2006) Isolation of viral hemorrhagic septicemia virus from muskellunge, Esox masquinongy (Mitchell), in Lake St. Clair, Michigan, USA reveals a new sublineage of the North American genotype. J Fish Dis 29:611-619

Fijan N, Sulimanovic D, Bearzotti M, Muxinic D and others (1983) Some properties of the Epithelioma papulosum cyprinid (EPC) cell line from carp Cyprinus carpio. Ann Virol (Inst Pasteur) 134:207-220

> Gaughan DJ (2001) Disease-translocation across geographic boundaries must be recognized as a risk even in the absence of disease identification: the case with Australian Sardinops. Rev Fish Biol Fish 11:113-123

Goodwin AE, Merry GE (2011) Mortality and carrier status of bluegills exposed to viral hemorrhagic septicemia virus genotype IVb at different temperatures. J Aquat Anim Health 23:85-91

Goodwin AE, Peterson JE, Myers TR, Money DJ (2004) Transmission of exotic fish viruses. Fisheries 29:19-23

> Harvell CD, Kim K, Burkholder JM, Colwell RR and others (1999) Emerging marine diseases-climate links and anthropogenic factors. Science 285:1505-1510

Hedrick RP (1996) Movements of pathogens with the international trade of live fish: problems and solutions. Rev Sci Tech Off Int Epizoot 15:523-531

Hervé-Claude LP, Carpenter TE, Hedrick RP (2008) Risk of introducing viral hemorrhagic septicemia virus (VHSV) to the Chilean South Pacific via sardine imports from Europe. Dis Aquat Org 78:199-207

> Hyatt AD, Hine PM, Jones JB, Whittington RJ and others (1997) Epizootic mortality in pilchard Sardinops sagax neopilchardus in Australia and New Zealand in 1995. II. Identification of a herpesvirus within the gill epithelium. Dis Aquat Org 28:17-29

Lumsden JS, Morrison B, Yason C, Russell S and others (2007) Mortality event in freshwater drum Aplodinotus

Editorial responsibility: Mark Crane, Geelong, Victoria, Australia grunniens from Lake Ontario, Canada, associated with viral haemorrhagic septicemia virus, Type IV. Dis Aquat Org 76:99-111

> Meyers TR, Short S, Lipson K (1999) Isolation of the North American strain of viral hemorrhagic septicemia virus (VHSV) associated with epizootic mortality in two new host species of Alaskan marine fish. Dis Aquat Org 38: 81-86

OIE (World Organization for Animal Health) (2009) Manual of diagnostic tests for aquatic animals, 6th edn. OIE, Paris

Perry K, Caveney L (2012) Chemical disinfectants. In: Caveney L, Jones B, Ellis K (eds) Veterinary infection: prevention and control. Wiley-Blackwell, Ames, IA, p 129-144

Phelps NBD, Patnayak DP, Jiang Y, Goyal SM (2012) Use of a one-step rRT-PCR for the surveillance of viral hemorrhagic septicemia virus in Minnesota. J Aquat Anim Health 24:238-243

Plumb JA, Zilberg D (1999) Survival of largemouth bass iridovirus in frozen fish. J Aquat Anim Health 11:94-96

Plumb JA, Wright LD, Jones VL (1973) Survival of channel catfish virus in chilled, frozen, and decomposing channel catfish. Prog Fish-Cult 35:170-172

Thompson TM, Batts WN, Faisal M, Bowser P and others (2011) Emergence of viral hemorrhagic septicemia virus in the North American Great Lakes region is associated with low viral genetic diversity. Dis Aquat Org 96:29-43

Thorarinsdottir KA, Arason S, Sigurgisladottir S, Gunnlaugsson VN, Johannsdottir J, Tornberg E (2011) The effects of salt-curing and salting procedures on the microstructure of cod (Gadus morhua) muscle. Food Chem 126:109-115

USDA-APHIS (US Department of Agriculture - Animal and Plant Health Inspection Service) (2008) Federal Order to prevent the spread of VHSV. Available at www.aphis. usda.gov/animal_health/animal_dis_spec/aquaculture/ downloads/vhs_fed_order_amended.pdf (accessed on 22 May 2012)

USFWS, AFS-FHS (US Fish and Wildlife Service, American Fisheries Society-Fish Health Section) (2010) Standard procedures for aquatic animal health inspections. In: AFS-FHS, FHS blue book: suggested procedures for the detection and identification of certain finfish and shellfish pathogens, 2010 edn. AFS-FHS, Bethesda, MD

VHSV Expert Panel \& Working Group (2010) Viral hemorrhagic septicemia virus (VHSV-IVb) risk factors and association measure derived by expert panel. Prev Vet Med 94:128-139

> Wang RY, Pirone TP (1996) Mineral oil interferes with retention of tobacco etch potyvirus in the stylets of Myzus persicae. Phytopathology 86:820-823

Winton J, Batts B, deKinkelin P, LeBerre M, Bremont M, Fijan N (2010) Current lineages of the epithelioma papulosum cyprinid (EPC) cell line are contaminated with fathead minnow, Pimephales promelas, cells. J Fish Dis 33: 701-704

WWF (World Wildlife Foundation) (2005) Risk on local fish populations and ecosystems posed by the use of imported feed fish by the tuna farming industry in the Mediterranean. World Wildlife Foundation Mediterranean Program, Rome

Submitted: September 23, 2012; Accepted: October 26, 2012 Proofs received from author(s): December 21, 2012 